Sādhanā Vol. 39, Part 6, December 2014, pp. 1509-1522. (C) Indian Academy of Sciences

\title{
Durability improvement assessment in different high strength bacterial structural concrete grades against different types of acids
}

\author{
RAMIN ANDALIB $^{1, *}$, M ZAIMI ABD MAJID $^{1}$, A KEYVANFAR $^{1}$, \\ AMIRREZA TALAIEKHOZAN ${ }^{3}$, MOHD WARID HUSSIN $^{1}$, \\ A SHAFAGHAT ${ }^{1}$, ROSLI MOHD ZIN ${ }^{1}$, CHEW TIN LEE ${ }^{2}$, \\ MOHAMMAD ALI FULAZZAKY ${ }^{3}$ and \\ HASRUL HAIDAR ISMAIL ${ }^{1}$
}

${ }^{1}$ Civil Engineering, Construction Research Alliance, Universiti Teknologi Malaysia (UTM), Skudai, Johor Bahru 81310, Malaysia

${ }^{2}$ Chemical Engineering -Bioprocess, Universiti Teknologi Malaysia (UTM), Skudai, Johor Bahru 81310, Malaysia

${ }^{3}$ Institute of Environmental and Water Resource Management, Universiti Teknologi Malaysia (UTM), Skudai, Johor Bahru 81310, Malaysia

e-mail: raminandalib@yahoo.com

MS received 24 November 2013; revised 19 April 2014; accepted 20 June 2014

\begin{abstract}
This paper provides an insight into a new biotechnological method based on calcite precipitation for achieving high strength bio-concrete durability. It is very clear that mineral precipitation has the potential to enhance construction material resistance towards degradation procedures. The appropriate microbial cell concentration $\left(30 * 10^{5}\right.$ cells $\left./ \mathrm{ml}\right)$ was introduced onto different structural concrete grades $(40$, 45 and $50 \mathrm{MPa}$ ) by mixing water. In order to study the durability of structural concrete against aggressive agents, specimens were immersed in different types of acids solution $\left(5 \% \mathrm{H}_{2} \mathrm{SO}_{4}\right.$ and $\left.\mathrm{HCl}\right)$ to compare their effects on $60^{\text {th }}, 90^{\text {th }}$ and $120^{\text {th }}$ day. In general, sulphuric acid and hydrochloric acid are known to be the most aggressive natural threats from industrial waters which can penetrate concrete to transfer the soluble calcium salts away from the cement matrix. The experimental results demonstrated that bio-concrete has less weight and strength losses when compared to the ordinary Portland cement concrete without microorganism. It was also found that maximum compressive strength and weight loss occurred during $\mathrm{H}_{2} \mathrm{SO}_{4}$ acid immersion as compared to $\mathrm{HCl}$ immersion. The density and uniformity of bio-concrete were examined using ultrasonic pulse velocity (UPV) test. Microstructure chemical analysis was also quantified by energy dispersive spectrometer (EDS) to justify the durability improvement in bacterial concrete. It was observed that less sulphur and
\end{abstract}

*For correspondence 
chloride were noticed in bacterial concrete against $\mathrm{H}_{2} \mathrm{SO}_{4}$ and $\mathrm{HCl}$, respectively in comparison to the ordinary Portland cement concrete due to calcite deposition.

Keywords. Bio-concrete; Bacillus; calcite precipitation; strength and durability; acidic immersion.

\section{Introduction}

Bio-concrete is a new research domain that can be used for construction materials to auto repair the micro-cracks which happens due to deterioration mechanism. The idea is to apply microorganisms in concrete, which will help in mineral precipitation in the small crack and tiny cavity areas. The presence of cracks can highly influence the strength and durability of the concrete and as a result they can provide a path through which moisture, chlorides, carbon dioxide and other aggressive agents can penetrate. Mostly, the cracks without suitable and immediate repair can expand, thus causing the deterioration and weakening of the concrete strength. Hence for this reason, there are some conventional repair methods being used which include materials such as mortar, epoxy and resins, however these are not considered sustainable.

The bio-concrete can be constructed using microbial application that is able to precipitate the calcite. A new technique based on bio-mineralization process by which living organisms can produce minerals to harden or stiffen the existing tissues to improve the durability. It was found that the bio-mineralization process will not interfere with the setting time of the concrete (Rao et al 2013). The bacteria should be cultured in a specific medium with a known concentration before the concrete ingredients are mixed together.

This process is called as MICP (microbiologically induced calcite precipitation). The fundamental law for this is to produce ammonia using the microbial urease enzyme. The equations (1) to (7) show a sequence of biochemical reactions that occur to form calcium carbonate with the help of ureolytic bacteria (Wu et al 2012). Urea is hydrolysed to carbamate (salt of carbamic acid) and ammonia in the presence of urease enzyme as shown in Eq. (1).

$$
\mathrm{CO}\left(\mathrm{NH}_{2}\right)_{2}+\mathrm{H}_{2} \mathrm{O} \stackrel{\text { Urease enzyme }}{\longrightarrow} \mathrm{NH}_{2} \mathrm{COOH}+\mathrm{NH}_{3} \text {. }
$$

Carbamate is hydrolysed to form ammonia and carbonic acid in a spontaneous manner as shown in Eq. (2).

$$
\mathrm{NH}_{2} \mathrm{COOH}+\mathrm{H}_{2} \mathrm{O} \rightarrow \mathrm{NH}_{3}+\mathrm{H}_{2} \mathrm{CO}_{3} .
$$

Carbonic acid is hydrolysed to form carbonate and hydrogen ion as shown in Eq. (3).

$$
\mathrm{H}_{2} \mathrm{CO}_{3}+\mathrm{H}_{2} \mathrm{O} \leftrightarrow \mathrm{HCO}_{3}^{-}+\mathrm{H}^{+} .
$$

Ammonia hydrolyses to form ammonium and hydroxide ion as seen in Eq. (4).

$$
2 \mathrm{NH}_{3}+2 \mathrm{H}_{2} \mathrm{O} \leftrightarrow 2 \mathrm{NH}_{4}^{+}+2 \mathrm{OH}^{-} .
$$

The reaction in Eq. (4) continuously produces hydroxide ion, which gives rise to increase in $\mathrm{pH}$ that shifts the overall equilibrium of bicarbonate ion $\left(\mathrm{HCO}_{3}^{-}\right)$towards the formation of carbonate ions as shown in Eq. (5)

$$
\mathrm{HCO}_{3}^{-}+\mathrm{H}^{+}+2 \mathrm{NH}_{4}^{+}+2 \mathrm{OH}^{-} \leftrightarrow \mathrm{CO}_{3}^{2-}+2 \mathrm{NH}_{4}^{+}+2 \mathrm{H}_{2} \mathrm{O} .
$$

Bacterial cell wall has negative charge and because of this reason, it is able to attract positively charged calcium ions $\left(\mathrm{Ca}^{2+}\right)$ to deposit on their cell wall surface (Eq. 6). The $\mathrm{Ca}^{2+}$ ions then 
react with $\mathrm{CO}_{3}^{2-}$ ions leading to the precipitation of calcium carbonate $\left(\mathrm{CaCO}_{3}\right)$ at the cell surface as shown in Eq. (7). This precipitation serves as nucleation site.

$$
\begin{gathered}
\mathrm{Ca}^{2+}+\mathrm{Cell} \rightarrow \mathrm{Cell}-\mathrm{Ca}^{2+}, \\
\mathrm{Cell}-\mathrm{Ca}^{2+}+\mathrm{CO}_{3}^{2-} \rightarrow \mathrm{CaCO}_{3}-\mathrm{Cell} \downarrow .
\end{gathered}
$$

Bacillus are a type of bacteria that can produce $\mathrm{CaCO}_{3}$ as a filler material and serve as a binding factor in concrete. $\mathrm{CaCO}_{3}$ can reduce capillary pores of concrete and improve durability and compressive strength. This characteristic feature is noticed in some concrete structures by healing and sealing the micro cracks. Hence concrete permeability was significantly reduced according to Jonkers et al (2008). Different Bacillus strains of spore-forming bacteria have been used by researchers in their studies for the purpose of self-healing of the concrete. i.e, Bacillus pasteurii (Gollapudi et al 1995; Bang \& Ramakrishnan 2001; Jonkers 2007, 2011; Zhong \& Islam 1995; Bang et al 2001; Santhosh et al 2001; Bachmeier et al 2002; Day et al 2003; Ramakrishnan et al 2001, 2005; Chahal et al 2012; Raijiwala et al 2009; Yoon et al 2001; Li et al 2012) and Bacillus sphaericus (Dick et al 2006; De Muynck et al 2008a, b; Van Tittelboom et al 2010; Wang et al 2010, 2012; Gavimath et al 2012; De Belie \& De Muynck 2009; De Belie et al 2005). Bacillus cohnii (Jonkers et al 2008; Jonkers \& Schlangen 2008; Jonkers et al 2010) and Bacillus pseudofirmus (Jonkers et al 2008; Jonkers \& Schlangen 2008; Jonkers et al 2010). Bacillus subtilis JC3 (Srinivasa et al 2011, 2012a, b; Park et al 2012), Bacillus megaterium (Achal et al 2008), and Bacillus alkalinitrilicus (Wiktor \& Jonkers 2011), Bacillus pasteurii has been reclassified as Sporosarcina pasteurii (Yoon et al 2001).

$\mathrm{CaCO}_{3}$, as a bio-product material during the process can be produced by the above mentioned type of Bacillus strains to fill the pores and improve the concrete durability.

The concrete durability is the resistance when exposed to decline conditions during its service life (Mullick 2007). The chemical attack, as one of the concrete durability aspects is also a significant investigation part which results in cracking, strength loss and deterioration (Prasad et al 2006).

However, many investigations have been made for the acid resistance behaviour of ordinary Portland cement (OPC) concrete but very limited information can be found on the bio-concrete durability studies. Thus, the aim of this experiment is to compare the relative performance of bacterial structural concrete to that of ordinary Portland cement (OPC) concrete which served as a control contained in the sulphuric and hydrochloric acid solutions $\left(\mathrm{H}_{2} \mathrm{SO}_{4}\right.$ and $\left.\mathrm{HCl}\right)$. Sulphuric acid and hydrochloric acid are also considered to be as the most aggressive threat from industrial waters. The acidic attack is influenced by the disintegration processes of the cement paste components (Turkel et al 2007). The acid attack risk can also be reduced by blocking the pathways present within the concrete porosity. $\mathrm{CaCO}_{3}$, from microorganism as filler material can decrease the porosity and improve the concrete durability. The above mentioned biochemical equations are the key evidences to prove why bacterial concrete is more resistant against acidic conditions which means ureolytic bacteria has good ability to increase the $\mathrm{pH}$ of environment through different biological metabolisms.

\section{Experimental work}

\subsection{Material preparation}

In this study, ordinary Portland cement (OPC) was complied with Type I Portland cement according to the Malaysian Standard MS 522 (2007) and was considered same as per ASTM C150 
(ASTMC150-05, 2005). The fine sand having a fineness modulus of 2.8 with saturated surface dry conditions, $10 \mathrm{~mm}$ aggregates and potable water as a mixing water were applied during the experiments for making the concrete specimens. The chemical composition of the OPC (mass $\%$ ), sand sieve analysis, coarse aggregate analysis and the properties of mixing water with DO meter are shown in tables $1-4$.

\subsection{Microorganism isolation and identification}

The isolation of microscopic organism in its life form is being considered as an important step in many biological experiments. A little bit of soil is included with so many microorganisms and it is necessary to kill some of them in boiling water to obtain a pure colony. Clostridium and

Table 1. The chemical composition of the OPC (mass \%).

\begin{tabular}{ccccccccc}
\hline $\mathrm{SiO}_{2}$ & $\mathrm{AL}_{2} \mathrm{O}_{3}$ & $\mathrm{Fe}_{2} \mathrm{O}_{3}$ & $\mathrm{CaO}$ & $\mathrm{MgO}$ & $\mathrm{Na}_{2} \mathrm{O}$ & $\mathrm{K}_{2} \mathrm{O}$ & $\mathrm{P}_{2} \mathrm{O}_{5}$ & $\mathrm{LOI}$ \\
\hline 43.1 & 5.0 & 2.6 & 46.0 & 1.1 & 0.2 & 0.5 & 0.2 & 1.3 \\
\hline
\end{tabular}

Table 2. Sand sieve analysis.

\begin{tabular}{lcccc}
\hline $\begin{array}{l}\text { Sieve size } \\
(\mathrm{mm})\end{array}$ & $\begin{array}{c}\text { Weight of sand } \\
\text { retained } \\
\text { (gram) }\end{array}$ & $\begin{array}{c}\text { Percentage of sand } \\
\text { retained } \\
(\%)\end{array}$ & $\begin{array}{c}\text { Cumulative percentage of } \\
\text { sand retained } \\
(\%)\end{array}$ & $\begin{array}{c}\text { Cumulative percentage of } \\
\text { sand passing } \\
(\%)\end{array}$ \\
\hline 5 & 6 & 1.2 & 1.2 & 98.8 \\
2.36 & 49 & 9.8 & 11 & 89 \\
1.18 & 112 & 22.4 & 33.4 & 66.6 \\
0.6 & 129 & 25.8 & 59.2 & 40.8 \\
0.3 & 108.8 & 21.76 & 80.96 & 19.04 \\
0.15 & 68 & 13.6 & 94.56 & 5.44 \\
Pan & 27.20 & 5.44 & 100 & 0 \\
& Sum $=500$ & & & \\
\hline
\end{tabular}

Table 3. $10 \mathrm{~mm}$ Coarse aggregate sieve analysis.

\begin{tabular}{lcccc}
\hline $\begin{array}{l}\text { Sieve size } \\
(\mathrm{mm})\end{array}$ & $\begin{array}{c}\text { Weight of aggregate } \\
\text { retained } \\
(\text { gram })\end{array}$ & $\begin{array}{c}\text { Percentage of } \\
\text { aggregate retained } \\
(\%)\end{array}$ & $\begin{array}{c}\text { Cumulative percentage of } \\
\text { aggregate retained } \\
(\%)\end{array}$ & $\begin{array}{c}\text { Cumulative percentage of } \\
\text { aggregate passing } \\
(\%)\end{array}$ \\
\hline 14 & 0 & 0 & 0 & 100 \\
10 & 738 & 14.76 & 14.76 & 85.24 \\
5 & 3864 & 77.28 & 92.04 & 7.96 \\
2.36 & 350 & 7 & 99.04 & 0.96 \\
Pan & 48 & 0.96 & 100 & 0 \\
& Sum $=5000$ & & & \\
\hline
\end{tabular}

Table 4. DO metere result for mixing water.

\begin{tabular}{|c|c|c|c|c|c|c|c|c|c|}
\hline $\begin{array}{l}\text { Temprature } \\
\left({ }^{\circ} \mathrm{C}\right)\end{array}$ & $\begin{array}{l}\text { Pressure } \\
(\mathrm{mm} \mathrm{Hg})\end{array}$ & $\begin{array}{l}\mathrm{DO} \\
(\%)\end{array}$ & $\begin{array}{c}\text { DO } \\
(\mathrm{mg} / \text { Liter })\end{array}$ & $\begin{array}{l}\text { Conductivity } \\
(\mu \text { second } / \mathrm{cm})\end{array}$ & $\begin{array}{c}\text { TDS } \\
\text { (mg/Liter) }\end{array}$ & $\begin{array}{l}\text { Salinity } \\
\text { (ppt) }\end{array}$ & PH & $\begin{array}{c}\mathrm{NH}_{4}^{+} \mathrm{N} \\
\text { (mg/Liter) }\end{array}$ & $\begin{array}{c}\mathrm{NH}_{3}^{-} \mathrm{N} \\
\text { (mg/Liter) }\end{array}$ \\
\hline 25 & 758.2 & 63 & 3.6 & 97.7 & 63.7 & 0.05 & 6.5 & 8.89 & 0.02 \\
\hline
\end{tabular}




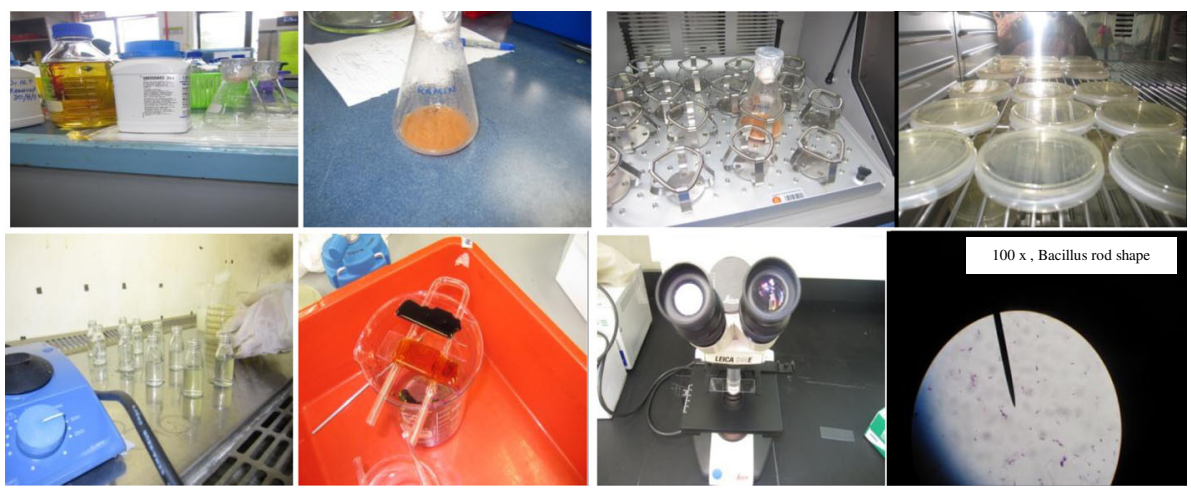

Figure 1. Various steps of bacterial isolation from soil.

Bacillus are the remaining bacterial spores which can withstand against boiling water. Subsequently, in the presence of oxygen, the Clostridium species can not grow to defend Hydrogen Peroxide $\left(\mathrm{H}_{2} \mathrm{O}_{2}\right)$ due to the enzyme shortage. So principally, remaining bacteria are Bacillus species since a drop of the boiled soil with nutrient broth is introduced on agar in petri dishes.

The soil samples $(1 \mathrm{~g})$ were suspended into $10 \mathrm{ml}$ of nutrient broth containing (peptone 5.0 $\mathrm{g} / \mathrm{L}$, yeast extract $3.0 \mathrm{~g} / \mathrm{L}$, distilled water) in a sterile conical flask separately. The flasks were placed in water bath and incubator shaker at $100^{\circ} \mathrm{C}$ and $30^{\circ} \mathrm{C}$ for $10 \mathrm{~min}$ and $24 \mathrm{~h}$, respectively. A loopful of nutrient broth was streaked onto nutrient agar plate containing (peptone $5.0 \mathrm{~g} / \mathrm{L}$, yeast extract $3.0 \mathrm{~g} / \mathrm{L}$, agar $12.0 \mathrm{~g} / \mathrm{L}$, distilled water) for each sample. Eventually, pure colonies were obtained using repeated streak plating technique. Figure 1 shows various steps of bacterial isolation from soil.

During this study, spread plate technique was carried out after serial dilution as to reduce the number of bacteria per unit sample volume, then the streak plate technique was performed using agar medium in order to isolate the individual bacterial cells and further the standard viable plate count was used to determine the colony-forming units (CFUs). Bergey manual of systematic bacteriology was also used as the main resource for determining the identity of bacteria.

Colony morphology including (shape, elevation, edge, and surface texture), cell morphology, gram stain reaction, oxygen requirements, glucose utilization and endospores are six characteristics of the unknown bacteria in order to approve the genus of bacteria. The result of characteristics examination was shown in table 5.

\subsection{Mix proportion determination and specimen testing}

To the structural concrete $\left(\mathrm{f}_{\mathrm{c}}=40 \mathrm{MPa}\right)$, five different cell concentration of microorganism from $10 * 10^{5}$ to $50 * 10^{5}$ cells were introduced and a significant increase in the compressive

Table 5. Colony morphology, cell morphology, gram stain reaction, and general properties of bacteria.

\begin{tabular}{|c|c|c|c|c|c|c|c|c|c|}
\hline \multirow{2}{*}{$\begin{array}{l}\text { Bacteria } \\
\text { genus }\end{array}$} & \multicolumn{4}{|c|}{ Colony morphology (from agar plates) } & \multirow{2}{*}{$\begin{array}{c}\text { Cell } \\
\text { Morphology }\end{array}$} & \multirow{2}{*}{$\begin{array}{c}\text { Gram } \\
\text { reaction } \\
(+/-)\end{array}$} & \multirow[b]{2}{*}{$\mathrm{O}_{2}$ Use } & \multirow{2}{*}{$\begin{array}{c}\text { Glucose } \\
\text { use }\end{array}$} & \multirow{2}{*}{$\begin{array}{c}\text { Endospore } \\
(\mathrm{Y} / \mathrm{N})\end{array}$} \\
\hline & Shape Elevation & Edge & Colour & Surface & & & & & \\
\hline Bacillus & Circular & Entire & Cream & Smooth & Bacillus-rod & + & aerobe & No gas & Yes \\
\hline
\end{tabular}


Table 6. Concrete mix design based on DOE method.

\begin{tabular}{lccccccc}
\hline Ingredients & Cement & $\begin{array}{c}\text { Water } \\
\text { Strength }\end{array}$ & $\begin{array}{c}\text { Fine } \\
\text { aggregate } \\
\mathrm{Kg} / \mathrm{m}^{3}\end{array}$ & $\begin{array}{c}\text { Kg } / \mathrm{m}^{3} \\
\text { aggregate } \\
\mathrm{Kg} / \mathrm{m}^{3}\end{array}$ & $\begin{array}{c}\text { Water/ } \\
\text { cement }\end{array}$ & $\begin{array}{c}\text { Design } \\
\text { slump } \\
\mathrm{mm}\end{array}$ & $\begin{array}{c}\text { Laboratory } \\
\text { slump } \\
\mathrm{mm}\end{array}$ \\
\hline $40 \mathrm{MPa}$ & 474 & 213.34 & 804.95 & 907.71 & 0.45 & $30-60$ & $45-50$ \\
$45 \mathrm{MPa}$ & 507.95 & 213.34 & 755.42 & 923.29 & 0.42 & $30-60$ & $40-45$ \\
$50 \mathrm{MPa}$ & 561.42 & 213.34 & 698.85 & 926.39 & 0.38 & $30-60$ & $30-35$ \\
\hline
\end{tabular}

strength cube was obtained in the case of $30 * 10^{5}$ cells of microorganism at different ages ( 3 , 7, 14, 28 and 60 days). This appropriate cell concentration $\left(30 * 10^{5}\right.$ cells) was applied again to the various grades of structural concrete $(40,45$ and $50 \mathrm{MPa})$ by the way of mixing water (per $\mathrm{ml}$ ) for the current experimental approach. A minimum of 3 cubes $(100 \times 100 \times 100 \mathrm{~mm})$ were prepared for each sample. Before the concrete was poured into the moulds, the moulds were lightly coated with a release agent (oil) to guarantee that the concrete does not stick to the mould and will make it easier to remove the specimen. Now, the freshly mixed concrete was placed into the mould as three equal layers by using a scoop and each layer was compacted 35 times with the help of compacting rod. After that the moulds were placed on a vibration table for 30 seconds (as over-vibration may lead to the segregation of aggregates). The time was considered sufficient because the surface became relatively smooth. Finally, the specimens were placed in a moist atmosphere $\left(26 \pm 4^{\circ} \mathrm{C}\right)$ and de-molded after $24 \mathrm{~h}$ by putting into the curing container. The focus of the research is to obtain high strength concrete. The compressive strength of the cubes with different grades of high strength structural concrete (40, 45 and $50 \mathrm{MPa}$ ) were determined at 14, 28, 60, 90 and 120 days. The American Concrete Institute (ACI) defines highstrength concrete as concrete with a compressive strength greater than $6000 \mathrm{psi}(\sim 40 \mathrm{MPa})$. The marginal difference ( $5 \mathrm{MPa}$ ) in the compressive strength was also chosen based on standard. The appropriate components of concrete based on DOE method according to the British standard are shown in table 6.

To study the durability of structural concrete against aggressive agents such as acidic conditions, the specimens were also immersed in different types of acidic solution [5\% solution of $\mathrm{H}_{2} \mathrm{SO}_{4}$ and $\mathrm{HCl}$ ]. Ultrasonic pulse velocity (UPV) test was applied to describe the concrete quality in terms of density, uniformity and homogeneity. This is on the basis of the fundamental rule that the velocity of ultrasonic pulse through any substance place trust in the density of the material. Measurements were made for the transit time (microsecond) of a high-frequency pulse $(54 \mathrm{KHz})$ over a measured path length (meter) between the transducers placed on the concrete surface (BS 1881 Part 203).

\subsection{Acid attack test}

The concrete cubes were prepared for acid attack test using appropriate concentration of microorganism $\left(30 * 10^{5}\right)$. The specimens were cast and cured in the mould for a day. Then the cubes were de-molded and kept in the curing container for 7 days. After that the specimens were put at ambient temperature conditions in order to provide a constant weight for 2 days. Finally, the specimens were weighed again and immersed in $5 \%$ of sulphuric acid $\left(\mathrm{H}_{2} \mathrm{SO}_{4}-95 \%\right)$ and hydrochloric acid (HCl-37\%) solution. The $\mathrm{pH}$ of the acidic media was 0.35 and checked periodically to maintain the $\mathrm{pH}$ at 0.35 . After several days of immersing in acidic solution for (60, 90 and 120 days), the specimens were taken out and washed in running water to eliminate loose components present on the surface and put back at ambient conditions for another 2 days to 

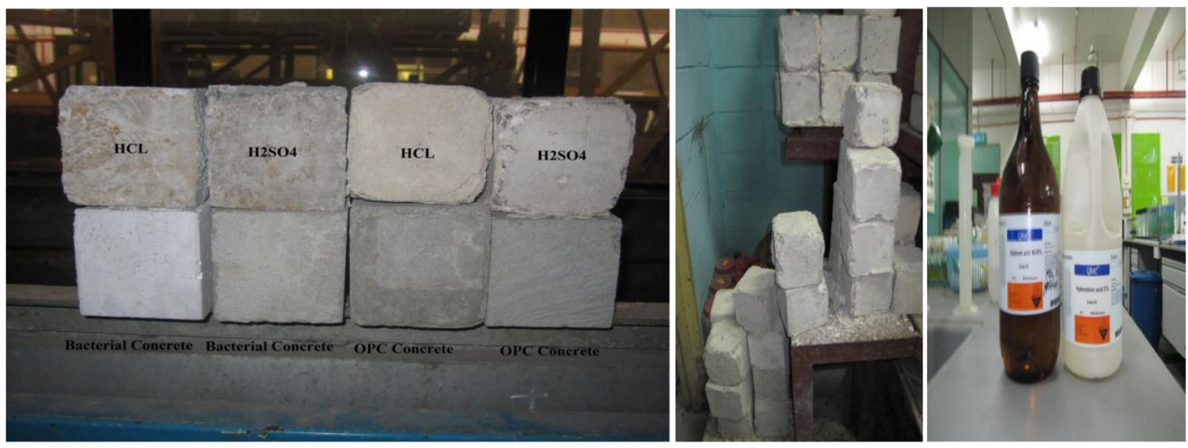

Figure 2. The appearance of specimens after immersion in $5 \% \mathrm{H}_{2} \mathrm{SO}_{4}$ and $5 \% \mathrm{HCl}$.

obtain a constant weight (the same condition when their initial weight was measured). Now the specimens were calculated for its strength and weight loss. The appearance of specimens after immersion in 5\% solution of $\mathrm{H}_{2} \mathrm{SO}_{4}$ and $\mathrm{HCl}$, are shown in figure 2.

\subsection{Microstructure chemical analysis by EDS}

Energy dispersive spectrometer (EDS) is a non-destructive test instrument which can provide the chemical analysis of the minute particles. In this study, microstructure chemical analysis of bacterial concrete was done to justify the durability improvement in terms of acidic condition ( $5 \%$ solution of $\mathrm{H}_{2} \mathrm{SO}_{4}$ and $\mathrm{HCl}$ ) in comparison to the ordinary Portland cement concrete.

\section{Results and discussion}

The main aim of this research is to investigate the effect of Bacillus strain bacteria in achieving different high strength structural concrete grade durability. The appropriate components of concrete were obtained based on DOE method according to the British standard. In DOE method, when the water-cement ratio decreased, the amount of cement was found to be increased. The required amount of water was also same for all of the water-cement ratios due to the selection of 30-60 mm slump in design. The amount of aggregate and concrete workability also increased because of the increase in water-cement ratio. Initially, the microorganism effect on the compressive strength of structural concrete based on $\mathrm{f}_{\mathrm{c}}=40 \mathrm{MPa}$ was examined with five different cell concentrations of microorganism from $10^{*} 10^{5}$ to $50^{*} 10^{5}$ cells (table 7). A significant increase in the compressive strength was obtained in the case of $30^{*} 10^{5}$ cells count per ml of mixing water (appropriate concentration) at different ages (3, 7, 14, 28 and 60 days). The maximum strength obtained was at $30^{*} 10^{5}$ concentration of microorganism at $60^{\text {th }}$ day up to $46.75 \mathrm{MPa}(12.60 \%$ increase). The compressive strength of specimens with more concentration other than $30^{*} 10^{5}$ was found to be reduced due to the presence of more microorganisms (more population) and nutrient shortage in comparison to the appropriate concentration $\left(30^{*} 10^{5}\right)$. Subsequently, the appropriate cell concentration $\left(30^{*} 10^{5}\right.$ cells) were again applied to various grades of structural concrete $(40,45$ and $50 \mathrm{MPa})$ for the current research. Figure 3 demonstrates the compressive strength of different structural concrete grades $(40,45$ and $50 \mathrm{MPa})$ obtained at $14^{\text {th }}, 28^{\text {th }}, 60^{\text {th }}$, $90^{\text {th }}$ and $120^{\text {th }}$ day without and with the appropriate concentration of microorganisms $\left(30^{*} 10^{5}\right)$. In this study, it was found that the compressive strength improvement of the highest grade of 


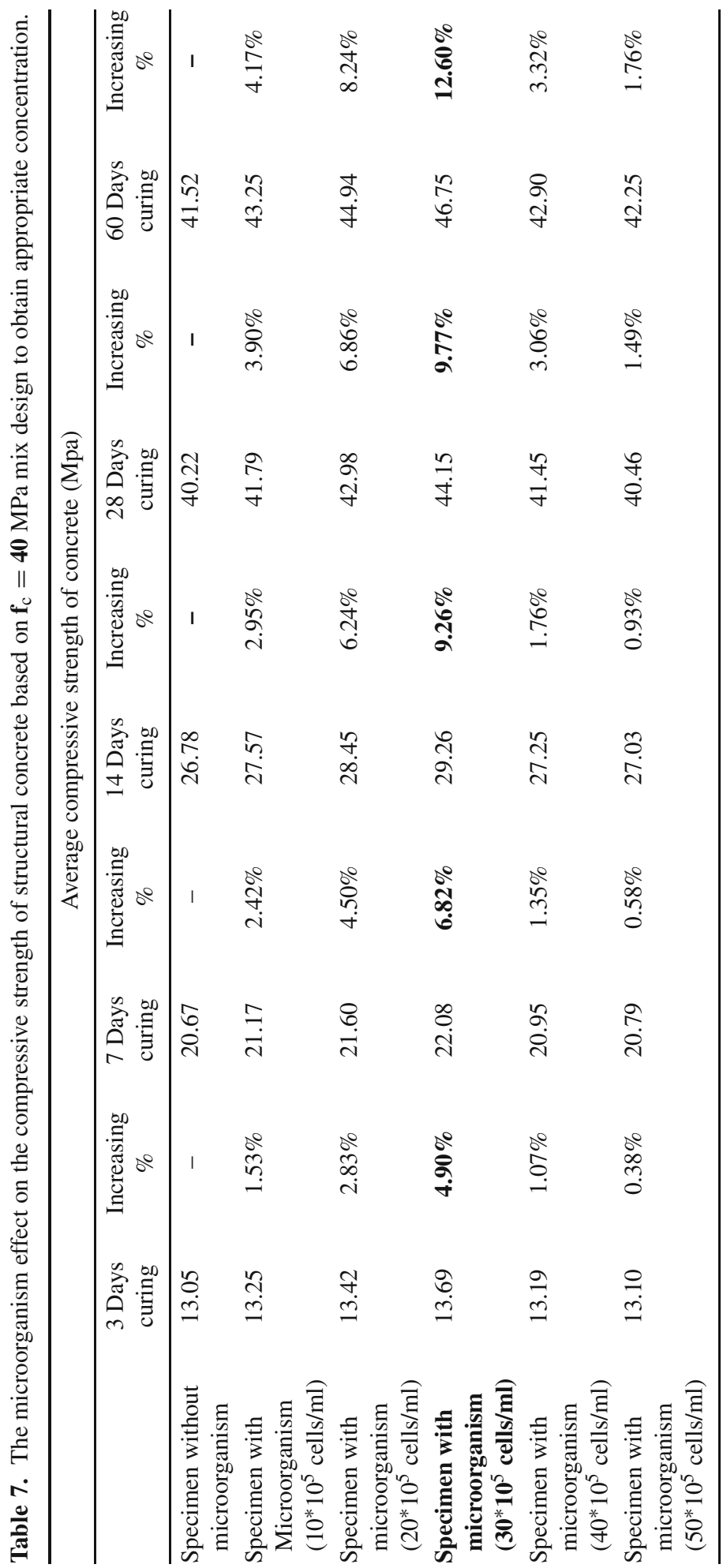




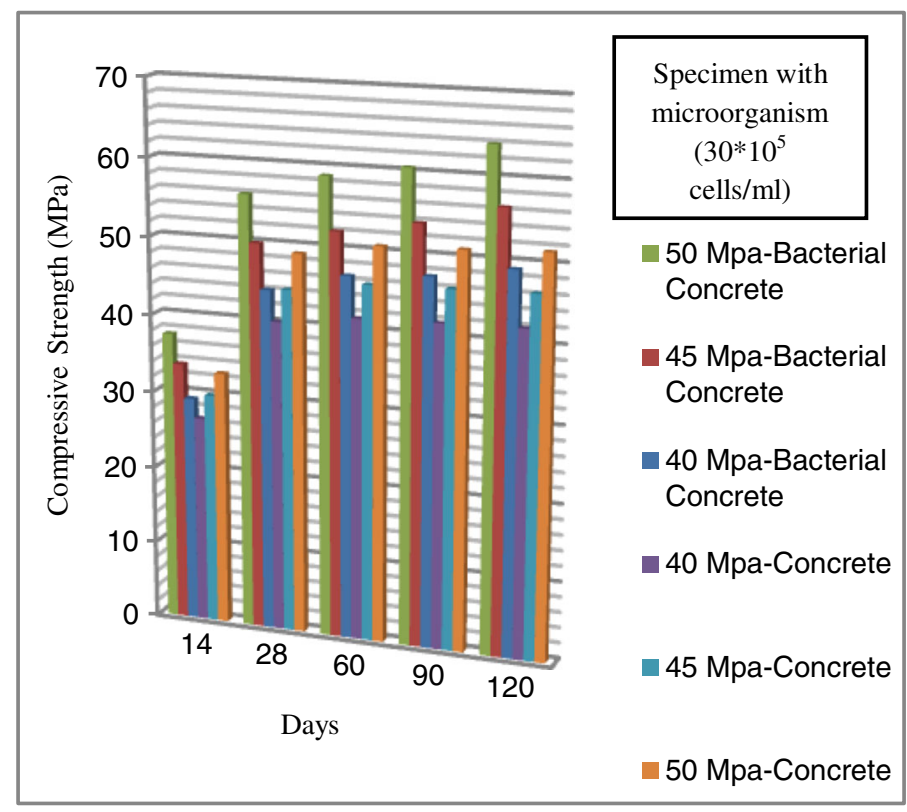

Figure 3. The microorganism effect on the compressive strength of different high strength structural concrete grades with an appropriate concentration- $30^{*} 10^{5}$ cells $/ \mathrm{ml}$ (average).

structural bacterial concrete (50 Mpa) was the highest. This improvement is due to the second hydration of some cement particles which were not attended during the first hydration and due to the biological activity of microorganisms to produce calcite. Figure $4 \mathrm{a}$ and b) also demonstrate the weight and strength loss of different structural concrete grades without and with microorganisms present in different types of acids. Figure 5 shows the ultrasonic pulse velocity (UPV) test resulted in three grades of structural concrete. In a comparative manner, higher velocity is achieved when concrete quality is high in terms of density and uniformity. In this research, it

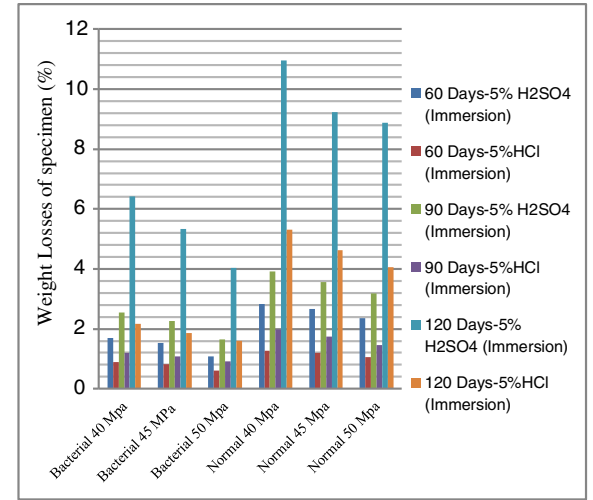

(a)

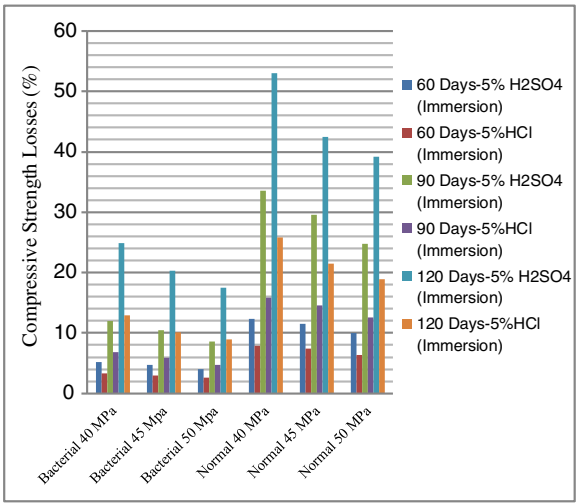

(b)

Figure 4. Weight (a) and strength (b) losses percentage of different high strength structural concrete grades without and with microorganism with an appropriate concentration- $30^{*} 10^{5}$ cells $/ \mathrm{ml}$ in different types of acids (immersion in $5 \% \mathrm{H}_{2} \mathrm{SO}_{4}$ and $5 \% \mathrm{HCl}$ )- (average). 


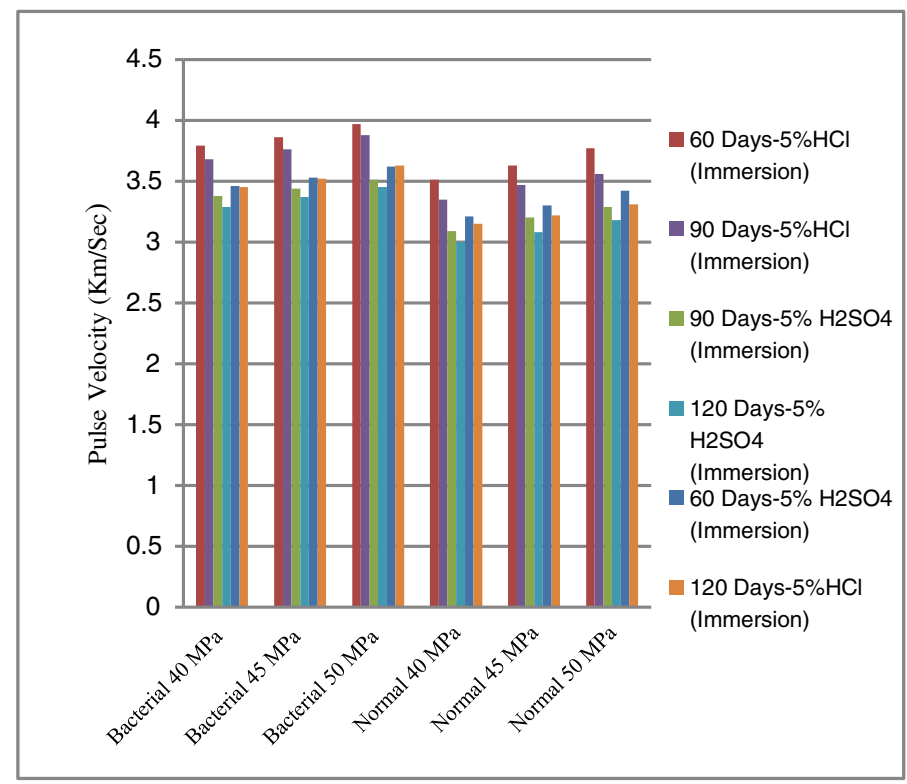

Figure 5. Ultrasonic Pulse Velocity (UPV) test result for different high strength structural concrete grades without and with microorganism with an appropriate concentration of $30^{*} 10^{5}$ cells $/ \mathrm{ml}$ in different types of acids (immersion in $5 \% \mathrm{H}_{2} \mathrm{SO}_{4}$ and $5 \% \mathrm{HCl}$ ) on (average).
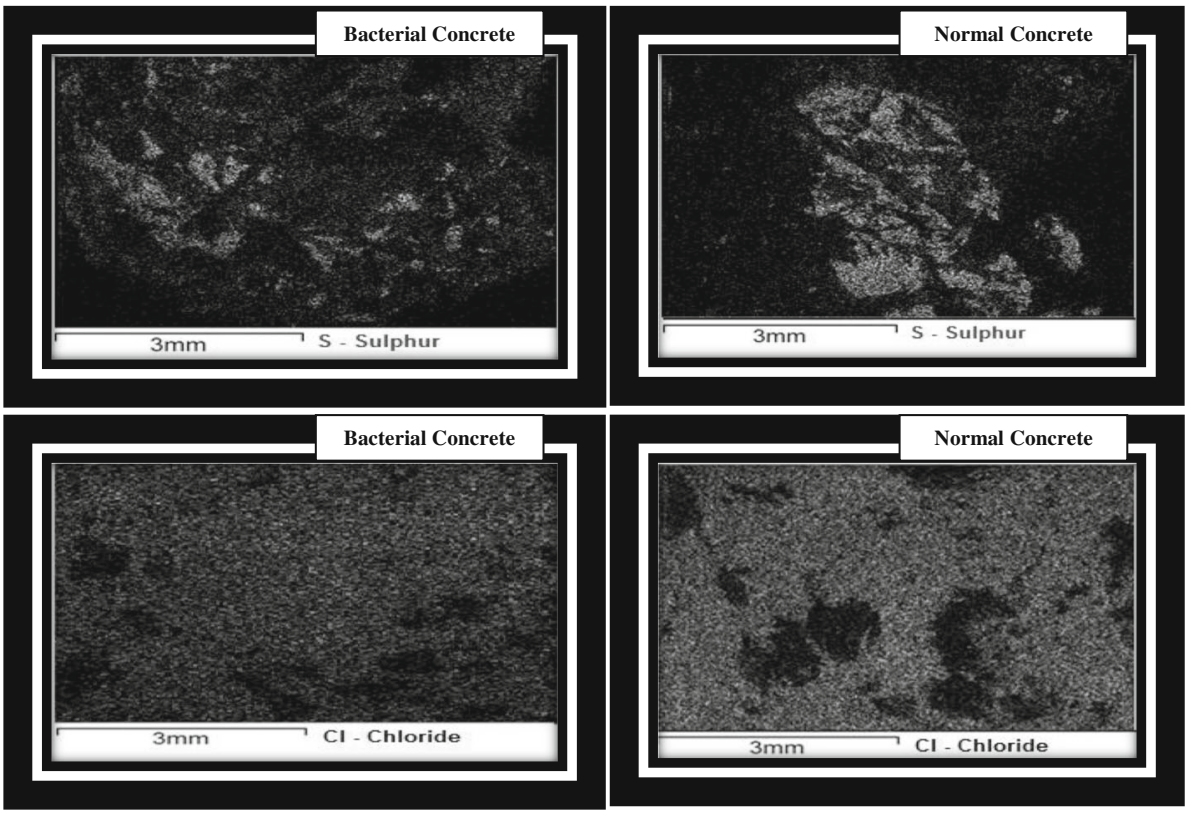

Figure 6. Microstructure of acid-attacked specimens (in $\mathrm{H}_{2} \mathrm{SO}_{4}$ immersion, light colour $=$ Sulphur and in $\mathrm{HCl}$ immersion, dark colour $=$ Chloride) . 
was found that the addition of microorganisms has a positive effect on the durability of different structural concrete grades. The study demonstrated that the bacterial concrete has less weight and strength loss than the ordinary Portland cement concrete without microorganism especially in the highest grade of structural bacterial concrete (50 Mpa). It was also monitored that the maximum compressive strength and weight loss occurred in the case of $\mathrm{H}_{2} \mathrm{SO}_{4}$ acid immersion as compared to $\mathrm{HCl}$. Subsequently, figures 6-10 demonstrate the microstructure chemical analysis

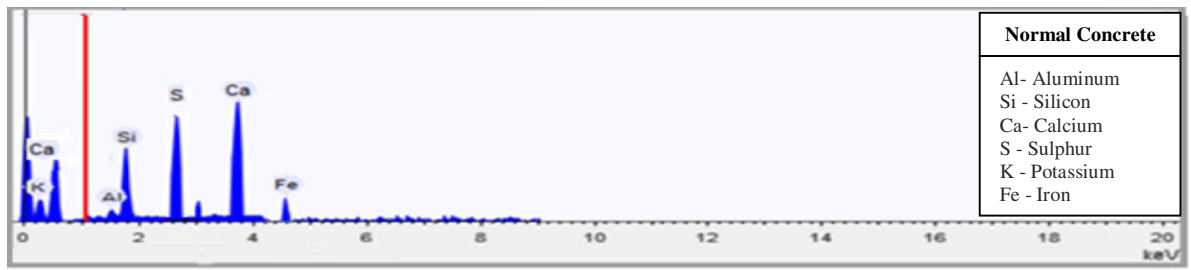

Figure 7. Elemental energy-dispersive spectrum for an acid-attacked specimen (normal concrete immersed in $\mathrm{H}_{2} \mathrm{SO}_{4}$ ).

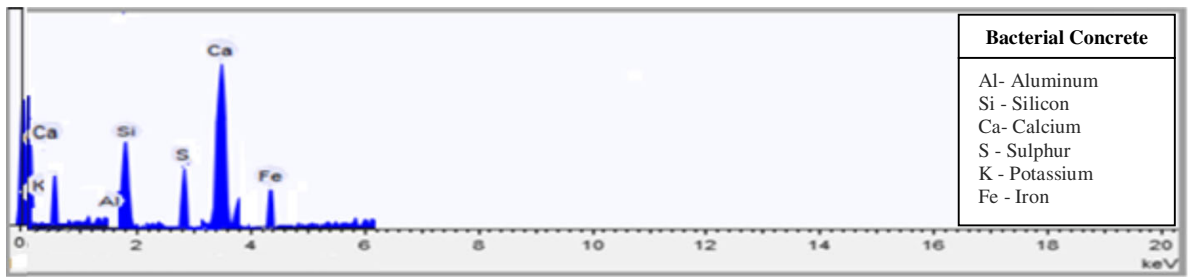

Figure 8. Elemental energy-dispersive spectrum for an acid-attacked specimen (bacterial concrete immersed in $\mathrm{H}_{2} \mathrm{SO}_{4}$ ).

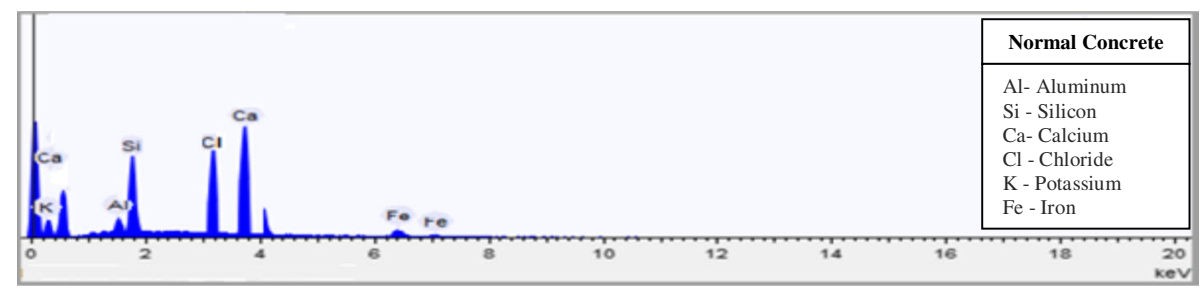

Figure 9. Elemental energy-dispersive spectrum for an acid-attacked specimen (normal concrete immersed in $\mathrm{HCl}$ ).

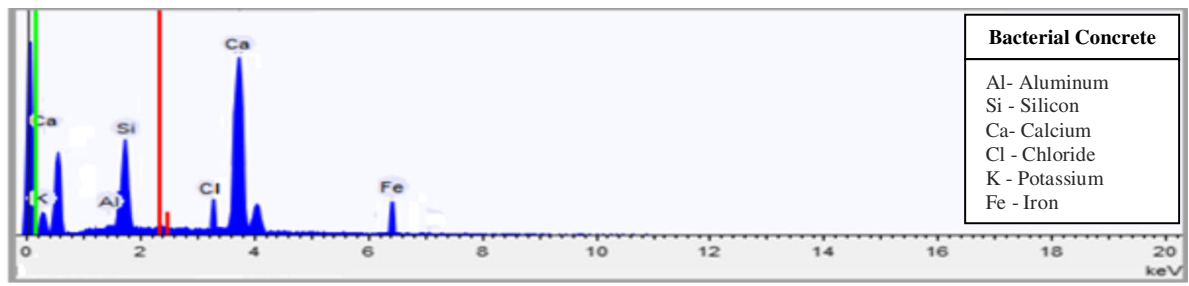

Figure 10. Elemental energy-dispersive spectrum for an acid-attacked specimen (bacterial concrete immersed in $\mathrm{HCl}$ ). 


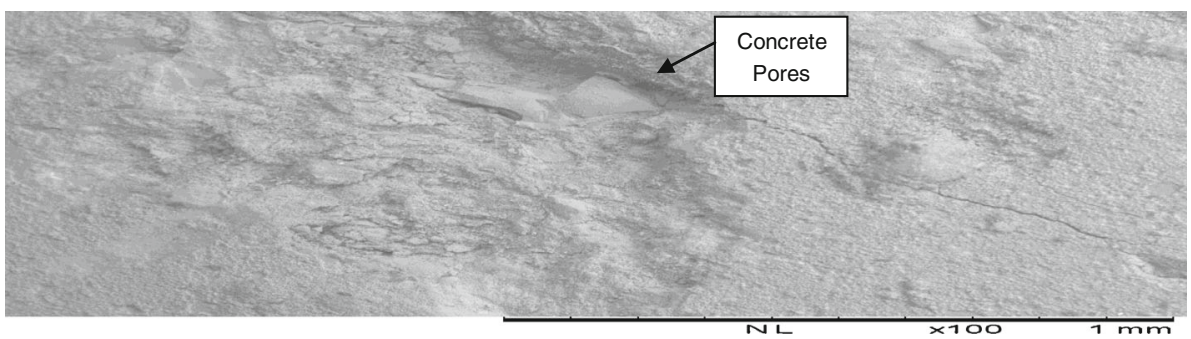

Figure 11. Specimen without microorganism under SEM instrument.

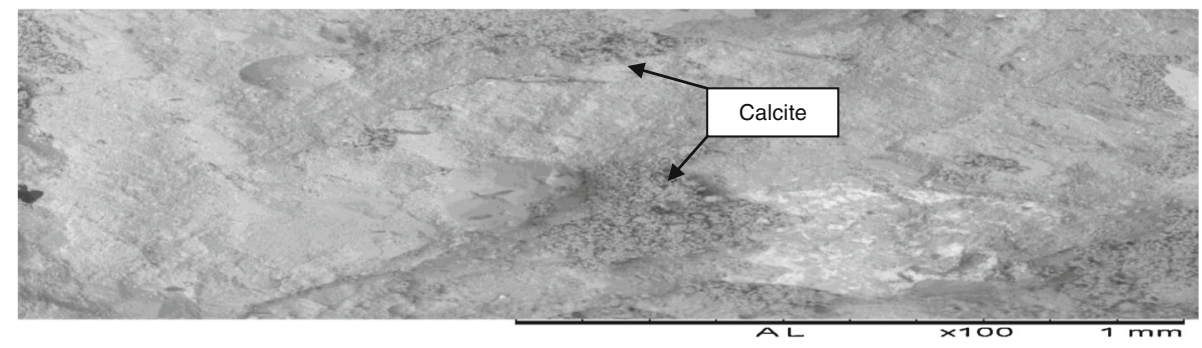

Figure 12. Specimen with appropriate concentration of microorganism $\left(30^{*} 10^{5}\right.$ cells $\left./ \mathrm{ml}\right)$ under SEM instrument.

of bio-concrete against $\mathrm{H}_{2} \mathrm{SO}_{4}$ and $\mathrm{HCl}$ in comparison to the ordinary Portland cement concrete by energy dispersive spectrometer (EDS). The micro-structural study had confirmed that less sulphur and chloride were occurred in bio-concrete against $\mathrm{H}_{2} \mathrm{SO}_{4}$ and $\mathrm{HCl}$ respectively in comparison to the ordinary Portland cement concrete due to calcite deposition. Eventually figures 11-12 by scanning electron microscope (SEM) study, gave good evidence to prove that the calcite precipitation took place.

\section{Conclusions}

In this study, it is found that the microscopic life form has a favourable outcome in determining the durability of different high strength structural concrete grades. The studies showed that bacterial concrete has less weight and strength loss when compared to the ordinary Portland cement concrete without microorganism in different types of acid solution. This improvement was due to the biological activity of bacteria to produce hydroxide ion, this gave rise to increase in $\mathrm{pH}$ which shifts the overall equilibrium of bicarbonate ion towards the formation of carbonate ions. It was also monitored that the maximum compressive strength and weight loss occurred in case of $\mathrm{H}_{2} \mathrm{SO}_{4}$ acid immersion as compared to $\mathrm{HCl}$. The durability studies also confirmed that the highest grade of bacterial concrete in this research $(50 \mathrm{MPa})$ had less weight and strength loss than the other grades in acidic condition. This enhancement was due to the formation of filler material within the concrete pores and because of the second hydration of some remaining cement particles which were not present in the first hydration of concrete process. Lastly, ultrasonic pulse velocity (UPV) and micro-structural tests results had proved that the density and uniformity of bacterial concrete are more than normal concrete even against aggressive conditions. Less sulphur and chloride were also revealed by energy dispersive spectrometer (EDS) in bio-concrete when compared with the ordinary Portland cement concrete against $\mathrm{H}_{2} \mathrm{SO}_{4}$ and $\mathrm{HCl}$ solutions. 


\section{Acknowledgements}

The authors thank the Ministry of Science, Technology and Innovation of Malaysia (MOSTI) - science fund - Vote. no 4S042) and the Construction Research Alliance of UTM (Universiti Teknologi Malaysia (Vote. no 00522) for financial support.

\section{References}

Achal V, Siddique R, Reddy M S and Mukherjee A 2008 Improvement in the compressive strength of cement mortar by the use of a microorganism - Bacillus megaterium, In: Excellence in Concrete Construction through Innovation: Proceedings of the conference held at the Kingston University, United Kingdom, 9-10 September 2008, p. 27, CRC Press

Bachmeier K L, Williams A E, Warmington J R and Bang S S 2002 Urease activity in microbiologicallyinduced calcite precipitation. J. Biotechnol. 93(2): 171-181

Bang S S and Ramakrishnan V 2001 Microbiologically-enhanced crack remediation (MECR), In: Proceedings of the International Symposium on Industrial Application of Microbial Genomes, pp. 3-13

Bang S S, Galinat J K and Ramakrishnan V 2001 Calcite precipitation induced by polyurethaneimmobilized Bacillus pasteurii. Enzyme Microb. Technol. 28(4): 404-409

Chahal N, Siddique R and Rajor A 2012 Influence of bacteria on the compressive strength, water absorption and rapid chloride permeability of concrete incorporating silica fume. Constr. Build. Mater. 37: 645-651

Day J L, Ramakrishnan V and Bang S S 2003 Microbiologically induced sealant for concrete crack remediation, In: Proc. of 16th Engineering Mechanics Conference, Seattle

De Belie N and De Muynck W 2009 Crack repair in concrete using biodeposition, In: Proceedings of the International Conference on Concrete Repair, Rehabilitation and Retrofitting (ICCRRR), Cape Town, South Africa, pp. 291-292

De Belie N, De Graef B, De Muynck W, Dick J, De Windt W and Verstraete W 2005 Biocatalytic processes on concrete: Bacterial cleaning and repair, In: 10th International Conference on Durability of Building Materials and Components (10-DBMC), pp. 17-20

De Muynck W, Debrouwer D, Belie N D and Verstraete W 2008a Bacterial carbonate precipitation improves the durability of cementitious materials. Cem. Concr. Res. 38: 1005-1014

De Muynck W, Cox K, De Belie N and Verstraete W 2008b Bacterial carbonate precipitation as an alternative surface treatment for concrete. Constr. Build. Mater. 22(5): 875-885

Dick J, De Windt W, De Graef B, Saveyn H, Van der Meeren P, De Belie N and Verstraete W 2006 Bio-deposition of a calcium carbonate layer on degraded limestone by Bacillus species. Biodegradation 17(4): 357-367

Gavimath C C, Mali B M, Hooli V R, Mallpur J D, Patil A B, Gaddi D, PTernikar C R and Ravishankera B E 2012 Potential application of bacteria to improve the strength of cement concrete. Int. J. Adv. Biotechnol. Res. ISSN 0976-2612 3(1): 541-544

Gollapudi U K, Knutson C L, Bang S S and Islam M R 1995 A new method for controlling leaching through permeable channels. Chemosphere 30(4): 695-705

Jonkers H M 2007 Self healing concrete: A biological approach, S van der Zwaag (ed.), Self healing materials: An alternative approach to 20 centuries of materials science 195-204

Jonkers H M 2011 Interview with Dr Henk Jonkers by A Damian Arnold, A freelance built-environment and civil engineering writer. INGENIA Issue 4, 6 March 2011

Jonkers H M and Schlangen E 2008 Development of a bacteria-based self healing concrete. In: Proc. int. FIB symposium, Vol. 1, pp. 425-430

Jonkers H M, Thijssen A and Schlangen E 2008 Development of self-healing concrete with the aid of bacteria. Cem. Concr. Res. 4: 78-81

Jonkers H M, Thijssen A, Muyzer G, Copuroglu O and Schlangen E 2010 Application of bacteria as self-healing agent for the development of sustainable concrete. Ecol. Eng. 36(2): 230-235 
Li P H, Wang K and Wang Z J 2012 Remediation and improvement of concrete by bacterial mediated carbonate deposition, Advanced Materials Research, www.scientific.net, 446: 3373-3376

Mullick A 2007 Performance of concrete with binary and ternary cement blends. Indian Concr. J. 81(1): $15-22$

Park S J, Park J M, Kim W J and Ghim S Y 2012 Application of Bacillus subtilis 168 as a multifunctional agent for improvement of the durability of cement mortar. J. Microbiol. Biotechnol. 22(11): 1568-1574

Prasad J, Jain D K and Ahuja A K 2006 Factors influencing the sulfate resistance of cement concrete and mortar. Asian J. Civil Eng. Housing 3(6): 259-268

Raijiwala D B, Prashant S, Hingwe P S and Babhor V K 2009 Bacterial concrete - An ideal concrete for historical structures, concrete solutions, London: Taylor \& Francis Group 185-190

Ramakrishnan V, Ramesh K P and Bang S S 2001 Bacterial concrete, smart materials, Alan R. Wilson, Hiroshi Asanuma, Editors, 168 Proceedings of SPIE 4234: 168-176

Ramakrishnan V, Panchalan R and Bang S S 2005 Improvement of concrete durability by bacterial mineral precipitation, Proceedings of 11th International Conference on Fracture, 20-25 March 2005, Turin, Italy

Rao M S, Reddy V S, Hafsa M, Veena P and Anusha P 2013 Bioengineered concrete-A sustainable self-healing construction material. Res. J. Eng. Sci. 2(6): 45-51

Santhosh K, Ramachandran S K, Ramakrishnan V and Bang SS 2001 Remediation of concrete using microOrganism, ACI, Materials Journal, http://www.concrete.org, 98:1 January-February 2001

Srinivasa Reddy V, Sunil Pratap Reddy S, Rao M S and Sasikala Ch 2011 Strength enhancement of cement mortar using microorganisms - An experimental study. Int. J. Earth Sci. Eng. ISSN 0974-5904 4(6): 933-936

Srinivasa Reddy V, Achyutha Satya K, Rao M S and Azmatunnisa M 2012a A Biological approach to enhance strength and durability in concrete structure, Int. J. Advances Eng. \& Technol., Sept 2012. CIJAET ISSN: 2231-1963, 4(2)

Srinivasa Reddy V, Sunil Pratap Reddy S, Seshagiri Rao M V and Sasikala Ch 2012b The Biological approach to enhance durability in concrete structures, 3rd World Congress on Biotechnology, September 13-15, 2012 Hyderabad International Convention Centre, Hyderabad, India

Turkel S, Felekoglu B and Dulluç S 2007 Influence of various acids on the physico-mechanical properties of pozzolanic cement mortars. Sadhana 32: 683-691

Van Tittelboom K, De Belie N, De Muynck W and Verstraete W 2010 Use of bacteria to repair cracks in concrete. Cem. Concr. Res. 40(1): 157-166

Wang J Y, Van Tittelboom K, De Belie N and Verstraete W 2010 Potential of applying bacteria to heal cracks in concrete, In: Proceedings of the Second International Conference on Sustainable Construction Materials and Technologies. Ancona, Italy, pp. 1807-1818

Wang J, Van Tittelboom K, De Belie N and Verstraete W 2012 Use of silica gel or polyurethane immobilized bacteria for self-healing concrete. Constr. Build. Mater. 26(1): 532-540

Wiktor V and Jonkers H M 2011 Quantification of crack-healing in novel bacteria-based self-healing concrete. Cem. Concr. Compos. 33(6): 763-770

Wu M, Johannesson B and Geiker M 2012 A review: Self-healing in cementitious materials and engineered cementitious composite as a self-healing material. Constr. Build. Mater. 28(1): 571-583

Yoon J, Lee K, Weiss N, Kho Y H, Kang K H and Park Y 2001 Sporosarcina aquimarina sp.nov., a bacterium isolated from seawater in Korea, and transfer of Bacillus globisporus (Larkin and Stokes 1967), Bacillus psychrophilus (Nakamura 1984)and Bacillus pasteurii (Chester 1898) to the genus Sporosarcina as Sporosarcina globispora comb. nov., Sporosarcina psychrophila comb.nov. and Sporosarcina pasteurii comb. nov., and emended description of the genus Sporosarcina. Int. J. Syst. Evol. Microbiol. 51(3): 1079-1086

Zhong L and Islam M R 1995 A new microbial plugging process and its impact on fracture remediation, Society of Petroleum Engineers. Annual technical conference pp. 703-715. https://www.onepetro.org/ conference-paper/SPE-30519-MS 